УДК 666.29.051.3, 621.793, 539.23

Іванченко С.Е., Умерова С.О., Барановський Д.І., Рагуля А.В.

Інститут проблем матеріалознавства НАН Украӥни ім. І.Н. Франщевича, м. Київ

\title{
ОТРИМАННЯ ТОНКИХ СУЦІЛЬНИХ КЕРАМІЧНИХ ПЛІВОК НА ОСНОВІ НАНОПОРОШКУ ВаТіОз МЕТОДОМ ПЛІВКОВОГО ЛИТТЯ
}

В роботі розглядається методика отримання плівок для багатомарових керамічних конденсаторів з товщииною близько 500 нм на ліофобній поверхні носія Mylar із силіконовим покриттям. Аналізуються фактори, щуо погіршують суцільність плівки, та пропонуються методи їх усунення. Також аналізується позитивний вплив зниження температури суспензій на якість отриманих із них плівок.

В работе рассматривается методика получения пленок для многослойных керамических конденсаторов с толщиной около 500 нм на лиофобной поверхности носителя Mylar с силиконовым покрытием. Анализируются факторы, ухудшающие ичелостность пленки, и предлагаются методы их устранения. Также анализируется положительное влияние понижения температуры суспензий на качество полученных из них пленок.

In this work the method of obtaining films for multilayer ceramic capacitors with a thickness of about $500 \mathrm{~nm}$ on lyophobic Mylar carrier surface with a silicone coating was investigated. Analyzes of the factors that degrade the integrity of the tape was provided and methods for their solution where offered. Also, the analysis of positive impact of lowering the suspensions temperature on quality of obtained tapes was conducted.

\section{Вступ}

У контексті стрімкого розвитку галузі друкованої електроніки особливий інтерес представляє технологія плівкового лиття, яка дозволяє отримувати тонкі еластичні плівки 3 високою щільністю, наперед заданою товщиною та рівномірним розподілом порошку в об’ємі. Використовуючи не складне обладнання, технологія дозволяє отримати плівки з будьякого матеріалу, який можна отримати у вигляді порошку, сама технологія $\epsilon$ високопродуктивною і екологічною. Плівкове лиття передбачає отримання суцільних планарних керамічних плівок (товщина від 3 мкм [1] до 3 мм [2]) шляхом лиття суспензій на машинах різної конструкції за допомогою стаціонарної або рухомої філь'єри, яка 
встановлюється на носій з резервуаром для суспензії і лезом. Дослідження методів, що дозволять отримувати тонші плівки методом плівкового лиття становлять значний інтерес, адже розширюють межі застосування технології та, у випадку багатошарових керамічних конденсаторів, дозволяють досягти збільшення ємності за рахунок зменшення товщини діелектричних шарів. В статі розглядається методика отримання тонких плівок (із товщиною близько 500 нм) на ліофобній поверхні носія. Використання ліофобних носіїв, у даному випадку це плівка Mylar з силіконовим покриттям, зумовлено потребою відділення плівки від носія для подальшого ламінування разом 3 іншими шарами керамічного конденсатора. В свою чергу ліофобне покриття погіршує змочуваність поверхні носія і тонка плівка суспензії, перебуваючи в рідкому стані після лиття, збирається на поверхні в краплі. Відділення плівки товщиною менше 1 мкм від носія, що не має ліофобного покриття, без руйнування в даному випадку є неможливим. Отже, задачею роботи було отримання суцільної тонкої плівки на ліофобному носії без зміни хімічного складу суспензії.

Об'єкти та методика експерименту. В якості твердої фази використовували нанопорошок $\mathrm{BaTiO}_{3}$ виробництва компанії «Нанотнхцентр» (ua) з розміром частинок 20 - 25 нм. У якості органічного в'яжучого застосовували розчин полімеру полівінілбутералю ПВБ з молекулярними масами від 40000 до 75000 у органічних розчинниках етанол та бутанол. Дибутилфталат використовували в якості пластифікатору. В роботі досліджувались суспензії наступного складу: концентрація розчину полімеру від 5 до 10 мас. \%, співвідношення полімер - пластифікатор: 2:1, співвідношення порошок - розчин полімеру: 1:2.

Приготування розчинів полімерів проводили шляхом розчинення порошкоподібного ПВБ протягом 30 хвилин за постійного перемішування на магнітній мішалці RCT basic фірми IKA за температури $45^{\circ} \mathrm{C}$. Для змішування розчинів полімера та пластифікатора з порошком використовували планетарний мономлин Pulverisette 6 фірми Fritsch, швидкість обертання 450 об/хв. Для перевірки впливу температури на реологічні властивості суспензії нагрівали та охолоджували за допомогою термостата Hauber ministat 125, реологічні дослідження проводили на ротаційному віскозиметрі Rheotest RN 4.1. 2D і 3D профілі поверхні, товщина, кількісні та якісні характеристики поверхні сирих плівок визначались за допомогою безконтактного інтерференційного 3D профілографу «Мікрон - альфа» фірми «Мікронсистема». Плівки із суспензій $\mathrm{BaTiO}_{3}$ формували на машині ТTC-1200 3 максимальною швидкістю руху носія $55 \mathrm{~cm} /$ хв. В якості носія використовували поліетилентерефталатну плівку з силіконовим антиадгезійним покриттям (Mylar).

Результати та обговорення. Основна проблема, що виникає під час лиття тонких плівок на ліофобний носій, - це порушення суцільності плівки. У випадку, коли суспензія 
нанесена тонким шаром, спостерігається руйнування поверхні, обумовлене через збирання суспензії в краплі і погане змочування ліофобної поверхні носія. Існує декілька способів вирішення цієї проблеми: зміна хімічного складу суспензії з метою покращення розтікання або використання носіїв без ліофобного покриття. Особливий інтерес викликає методика усунення дефектів у випадку, коли обидва способи є неприйнятними.

Склад суспензій, що використовували в роботі, поданий в табл. 1.

Таблиця 1.

Склад досліджуваних суспензій

\begin{tabular}{|c|c|c|c|c|c|c|}
\hline \multirow{2}{*}{$\begin{array}{c}\text { Назва } \\
\text { суспензії }\end{array}$} & \multirow{2}{*}{$\begin{array}{c}\text { Вміст } \\
\text { порошку } \\
\mathrm{BaTiO}_{3} \\
\text { \% мас }\end{array}$} & \multicolumn{2}{|c|}{ Вміст розчинника, \% мас } & \multirow{2}{*}{ Вміст ПАР, \% мас } & \multirow{2}{*}{$\begin{array}{c}\text { Вміст суміші полімерів } \\
3 \text { різною } \\
\text { молекулярною масою, } \\
\text { \% мас }\end{array}$} & \multirow{2}{*}{$\begin{array}{c}\text { Вміст } \\
\text { пластифікатору } \\
\text { ДБФ, \% мас }\end{array}$} \\
\hline & & Етанол & Бутанол & & & \\
\hline TCS-23 & 26,72 & - & 63,50 & 0,80 & 4,28 & 4,70 \\
\hline TCS-27 & 23,42 & 66,04 & - & 0,70 & 4,68 & 5,15 \\
\hline
\end{tabular}

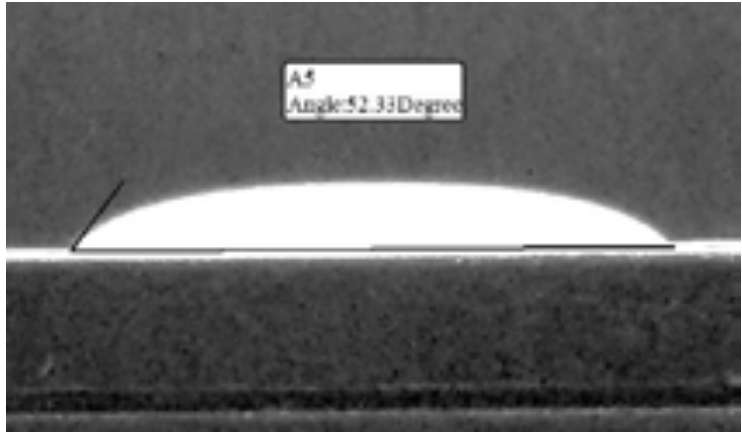

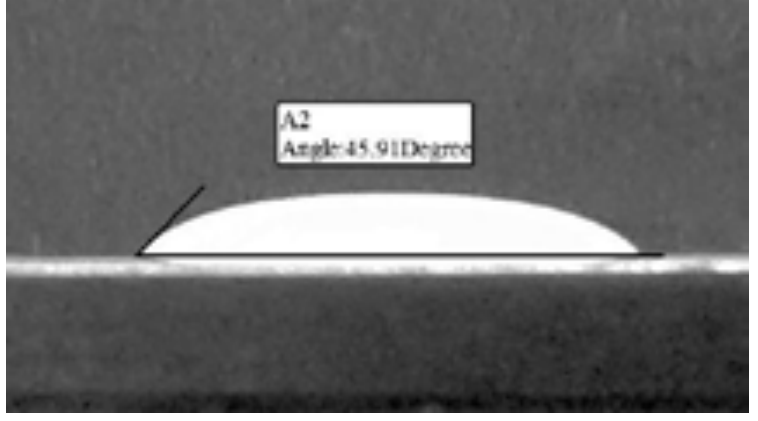

6

Рис. 1. Зміна крайового кута змочування суспензій з різною температурою: $\mathrm{a}-\mathrm{T}=25^{\circ} \mathrm{C} ; 6-\mathrm{T}=5^{\circ} \mathrm{C}$.

Покращити розтікання суспензії на носії вдалося за рахунок іiі попереднього охолодження. Як видно з рис. 1 , охолодження суспензії до $5^{\circ} \mathrm{C}$ зменшило кут змочування на $7^{\circ}$

В роботі [3] збільшення крайових кутів при підвищенні температури розглядається як аномалія. Передбачається, що в таких системах тверде тіло надає орієнтуючий вплив на розташування молекул у тонкому шарі. Можлива причина погіршення змочування при високих температурах полягає в зміні хімічного складу контактуючих речовин. Наприклад, склад рідкої фази може змінитися внаслідок гідролізу, окислення, піролізу, склад твердої поверхні - через окислення або дегідратації. Продукти хімічної реакції, що утворюються в рідкій фазі, можуть адсорбуватися на твердій основі, утворюючи на ній плівку з низьким поверхневим натягом: в результаті змочування різко погіршується. 
Експерименти проводилися з метою виявлення факторів, які дозволяють отримувати більш якісні плівки з охолоджених суспензій та визначення мінімально можливої товщини плівки, яку можна отримати при застосуванні методу Tape Casting. Для отримання мінімальної товщини лезо філь'єри було опущене в найнижче положення, фактично лиття проводилося при закритій філь'єрі. Швидкість руху носія складала 0,55 м/хв. Лиття проводилося на ліофобну сторону носія; було отримано дві плівки із суспензії TCS-27 3 температурою $25^{\circ} \mathrm{C}$ та з суспензії, охолодженої до температури $5^{\circ} \mathrm{C}$.

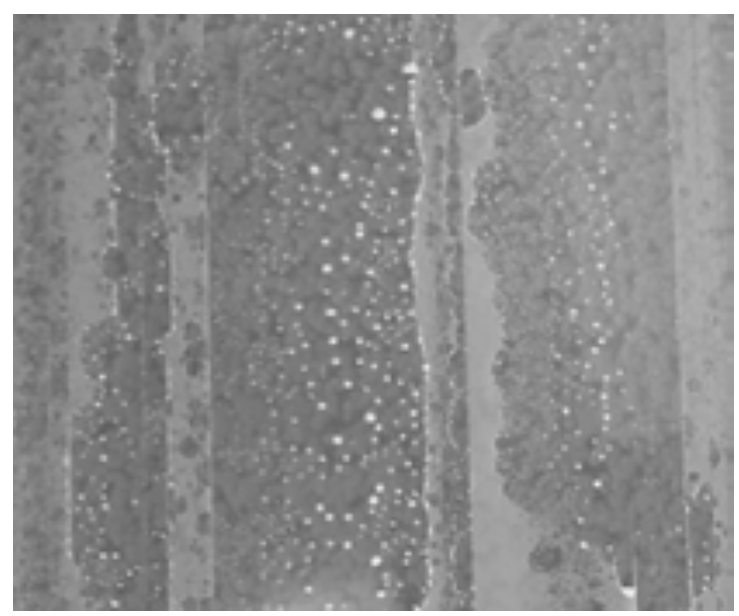

Рис. 2. Фотографія ділянки фрагментованої плівки отриманої із суспензії TCS-27 при температурі $25^{\circ} \mathrm{C}$

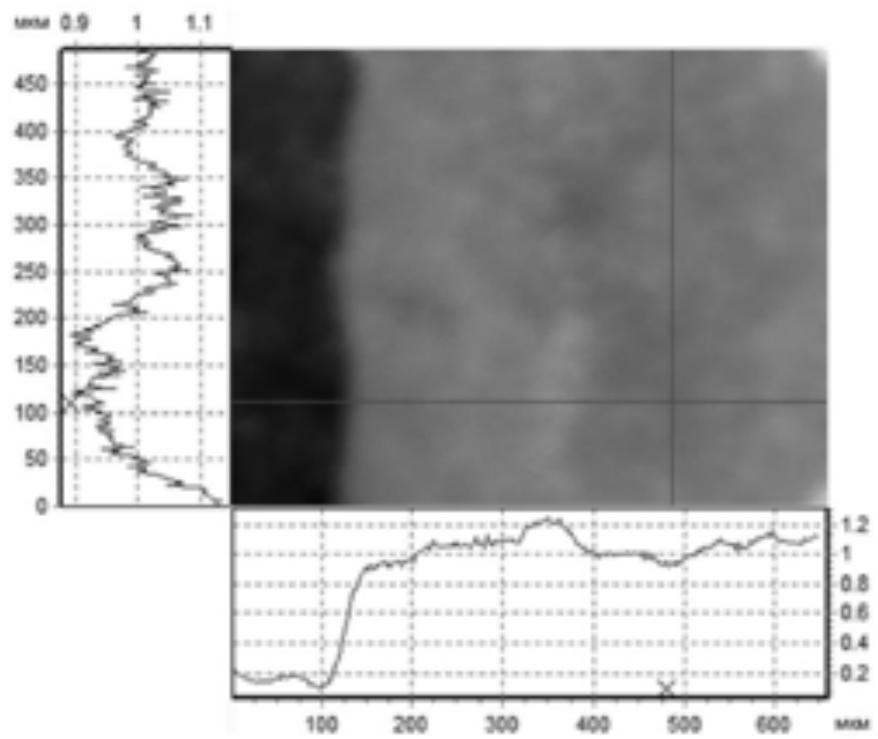

Рис. 3. 2-D профіль окремої суцільної ділянки фрагментованої плівки отриманої із суспензії TCS-27 при температурі $25^{\circ} \mathrm{C}$ 
Критерії шорсткості плівки, отримані під час профілографічних дослідженнь, склали: $\mathrm{Rz}=0.1107$ мкм, $\mathrm{Ra}=0.04336$ мкм.

На початку лиття обидві суспензії наносилися на носій тонким рівномірним шаром, однак суспензія 3 температурою $25^{\circ} \mathrm{C}$ через деякий час почала збиратися в краплі, руйнуючи поверхню плівки (рис. 2 та 3). Охолоджена суспензія залишалася в стані рівномірної тонкої плівки аж до повного висихання на повітрі (рис. 4 та 5).

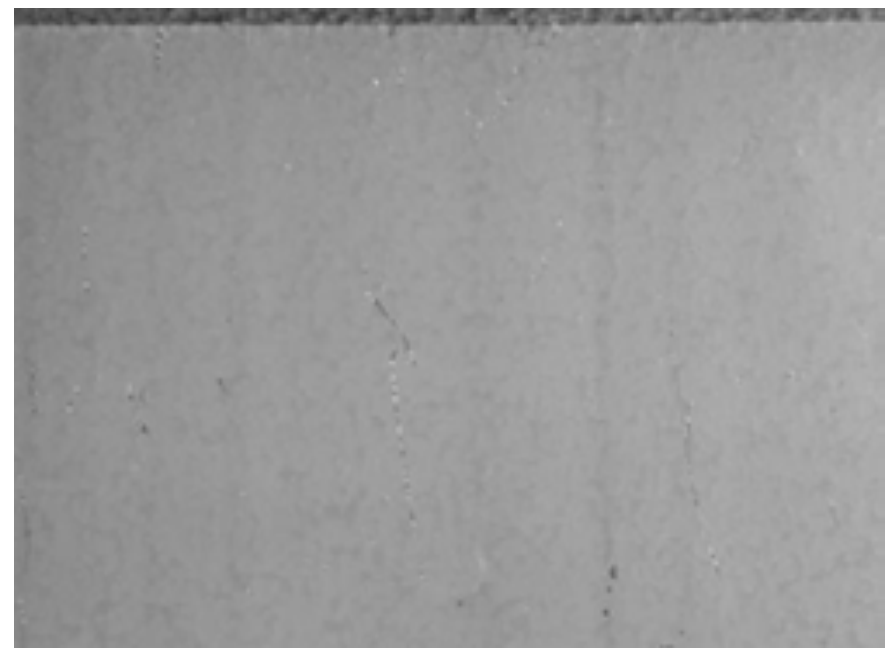

Рис. 4. Фотографія ділянки плівки отриманої із суспензії TCS-27 при температурі $5^{\circ} \mathrm{C}$

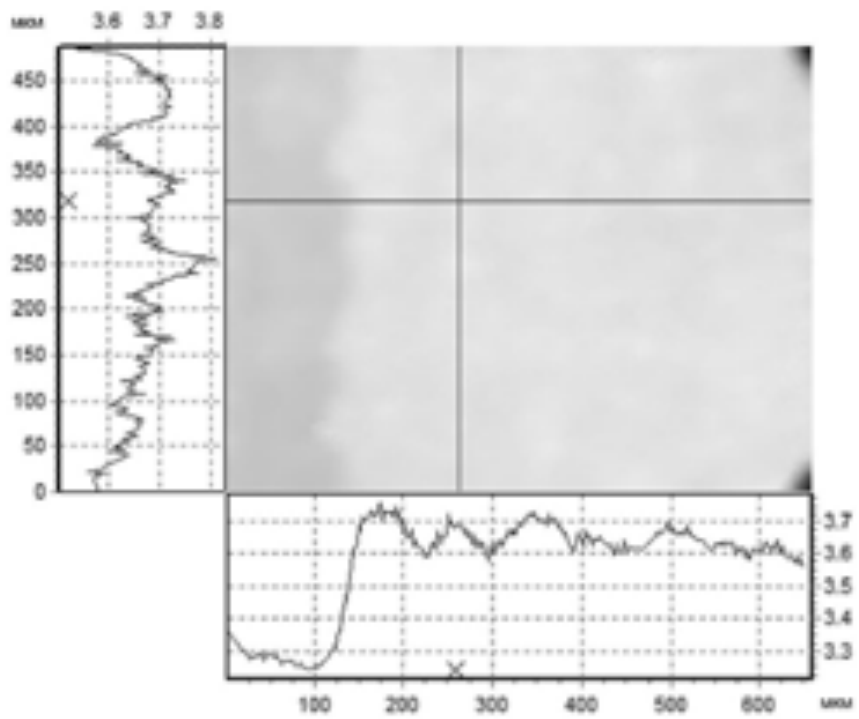

Рис. 5. 2-D профіль плівки отриманої із суспензії TCS-27 при температурі $5^{\circ} \mathrm{C}$ 
Критерії шорсткості, плівки отримані під час профілометричних досліджень склали: $\mathrm{Rz}=0,08589$ мкм, $\mathrm{Ra}=0,02474$ мкм. Частина суспензії, що під час лиття довше перебувала в резервуарі філь'єри при кімнатній температурі і нагрілася, виявляла поведінку подібну до суспензії кімнатної температури і також почала збиратися в краплі.

Отримані дані показують, шо попереднє охолодження суспензії не тільки дозволило отримати суцільну плівку на ліофобній поверхні носія без зміни хімічного складу, а i зменшило товщину та шорсткість плівки в порівнянні 3 окремими суцільними ділянками плівки отриманої із суспензії при температурі $25^{\circ} \mathrm{C}$. Більшу товщину суцільних ділянок плівки, отриманої із суспензії при температурі $25^{\circ} \mathrm{C}$ можна пояснити тим, що через погане змочування суспензія зібралася в острівки, збільшуючи об'єм суспензії в окремій точці, а відтак - товщину.

Подальші дослідження проводилися 3 метою встановлення впливу температури суспензії на товщину та шорсткість плівок при збільшеній висоті зазору філь'єри. В цьому випадку погане змочування ліофобної поверхні носія не призводило до збирання суспензії в окремі краплі і фрагментування плівки. Для визначення впливу температури на в'язкість і характер течії були проведені реологічні дослідження суспензії TCS-23 при різних температурах.

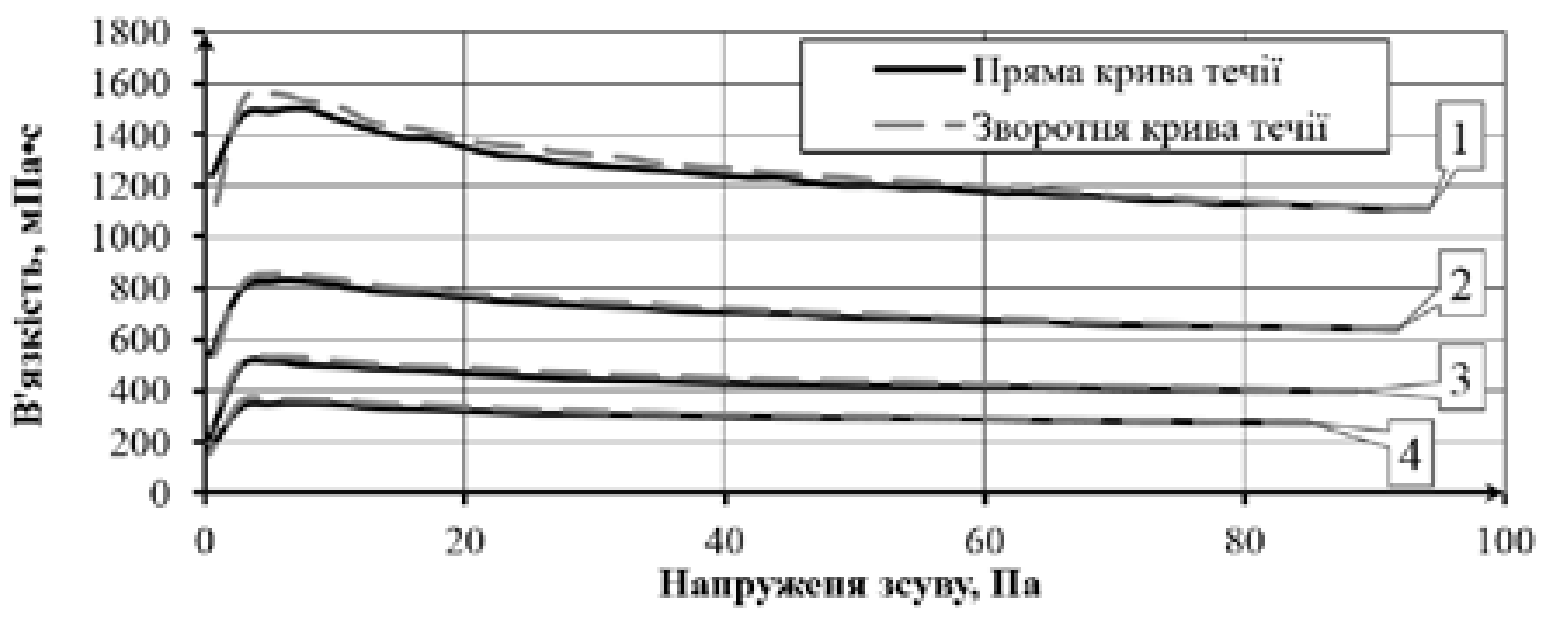

Рис. 6. Залежність в'язкості суспензії TCS-23 від напруження зсуву при різних температурах: $1-\mathrm{T}=5^{\circ} \mathrm{C} ; 2-\mathrm{T}=15^{\circ} \mathrm{C} ; 3-\mathrm{T}=25^{\circ} \mathrm{C} ; 4-\mathrm{T}=35^{\circ} \mathrm{C}$. 


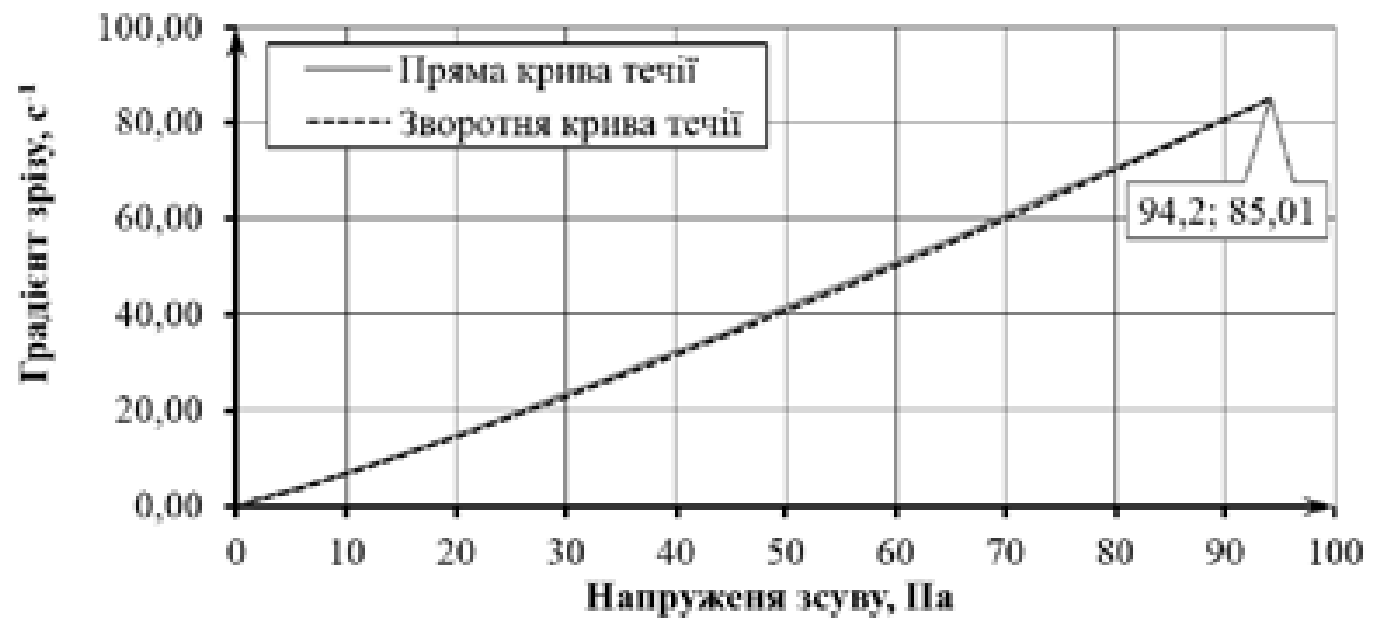

Рис. 7. Залежність градієнту зрізу від напруження зсуву для суспензії TCS-23 при температурі $5^{\circ} \mathrm{C}$

Виходячи з отриманих реологічних кривих (рис. 6), можна зробити висновок, що всім суспензіям притаманний псевдопластичний характер течії з незначною тиксотропією, яка проявляється сильніше при нижчих температурах. Також спостерігається збільшення граничного напруження зсуву. Різниця у в'язкості між суспензіями різної температури зменшується зі збільшенням напруження зсуву.

Одразу після проведення реологічних досліджень проводилося лиття охолоджених та нагрітих суспензій. Суспензія TCS-23 була розділена на 3 частини, температура яких на момент лиття складала 5,25 та $45^{\circ} \mathrm{C}$ відповідно. Лиття проводилося на литтєвій машині ТTC1200 при висоті зазору філь'єри 10 мкм та швидкості руху носія 0,55 м/хв. у всіх трьох випадках.

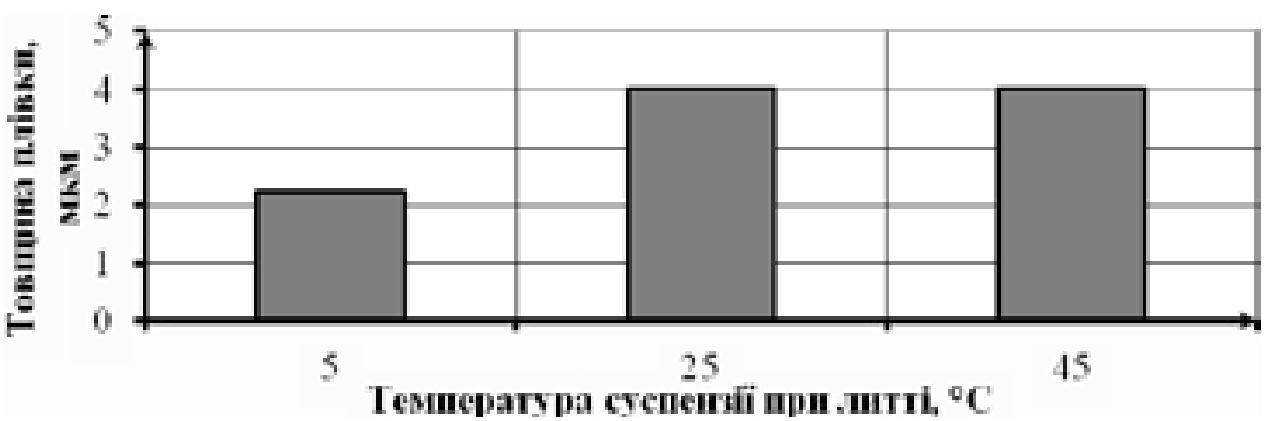

Рис. 8. Залежність товщини плівок від температури суспензії TCS-23 при литті 


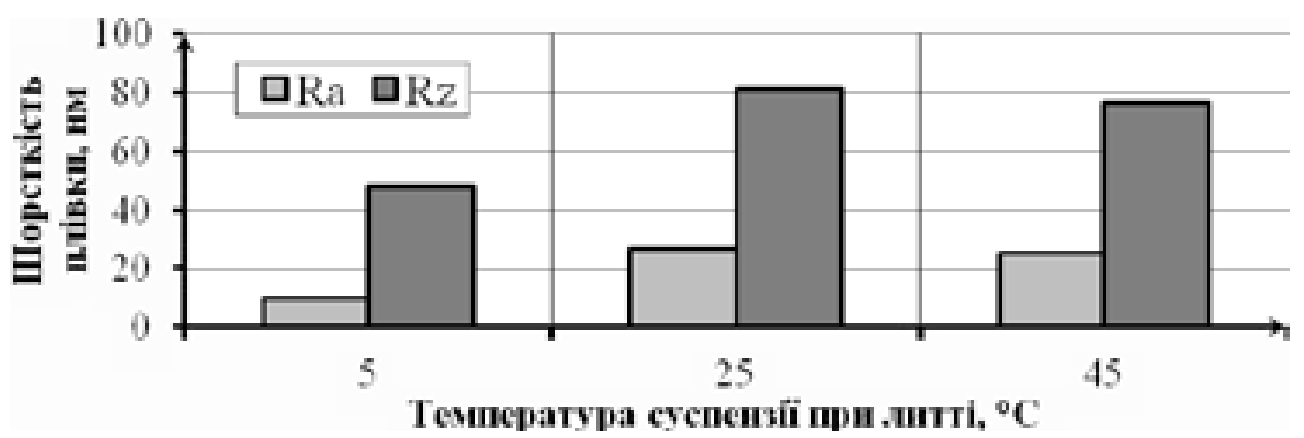

Рис. 9. Залежність шорсткості плівок від температури суспензії TCS-23 при литті

В’язкість охолодженої суспензії значно вище ніж нагрітих, і можна припустити, що товщина плівок, отриманих з охолоджених суспензій, повинна була збільшитися, однак на практиці спостерігається протилежний ефект. Це явище можна пояснити тим, що, при зменшенні висоти зазору філь'єри до мінімальних значень, значно зростає градієнт зрізу, що діє на суспензію.

Градієнт зрізу для рідин, що течуть між двома паралельними пластинами, одна 3 яких рухається з постійною швидкістю, а інша закріплена нерухомо (течія Куетта), визначається рівнянням:

$$
\dot{\gamma}=\frac{v}{h}
$$

Де $\dot{\gamma}$ - градієнт зрізу, що виміряється в с $\mathrm{c}^{-1}$

$u$ - швидкість пластини, що рухається, м/с

$h$ - відстань між двома паралельними пластинами, м

Відповідно до формули (1), приймаючи лезо філь'єри і рухому підкладку для лиття за дві паралельні пластини, можна говорити про те, що зі зменшенням висоти зазору філь'єри до мінімальних значень градієнт зрізу буде значно зростати. Теоретично розраховане значення градієнту зрізу при висоті зазору філь'єри 10 мкм та швидкості руху носія 0,55 см/хв. становитиме близько $917 \mathrm{c}^{-1}$. Цей показник значно переважає градієнт зрізу, що відповідає максимальному напруженню зсуву охолодженої до $5{ }^{\circ} \mathrm{C}$ суспензії TCS-23, і становить відповідно $85 \mathrm{c}^{-1}$ та 94 Па (рис. 7). 3 цього випливає, що структура суспензії під дією такого градієнту зрізу повністю зруйнована. Г. Шрамм зазначає, що ступінь зниження в’язкості при збільшенні швидкості зсуву псевдопластичних рідни не є постійним в усьому інтервалі швидкостей зсуву. Коли швидкість зсуву збільшується до такого ступеня, що викликана нею орієнтація молекул чи частинок значно переважає дезорієнтуючий вплив 
броунівського руха, в’язкість рідини різко падає. При надзвичайно високих швидкостях зсуву в’язкість буде асимптотично наближатися до певної кінцевої постійної величини. Перехід до ще більш високих швидкостей зсуву вже не зможе призвести до подальшого зниження в’язкості, тому що оптимальні умови довершеної орієнтації частинок уже досягнуто [4].

Ще один фактор, яким можна пояснити отримання тонших плівок з більш в’язких охолоджених суспензій, - це час спаду внутрішніх напружень або час релаксації структури. Розплави полімерів є не тільки в'язкими, але і в значній мірі пружними рідинами. Пружні деформації молекул та/або елементів об’єму згодом будуть релаксувати. Найбільш значна релаксація відбувається відразу після того, як полімер переходить у стан спокою після закінчення лиття. У листових виробах із полімерів, охолоджених до кімнатної температури, пружні деформації (елементи типу розтягнутих спіралей) «заморожуються» в полімері, що затвердів. При кімнатній температурі спад внутрішніх напружень протікає протягом тривалого періоду часу (години, дні або навіть тижні) шляхом, відомим як «мікротечія» на молекулярному рівні, що призводить до спотворення розмірів виробів або утворення мікротріщин. Більш в'язкі компоненти полімерної композиції, які досягають дуже високої в'язкості при майже нульовій швидкості зсуву, коли плівка переходить в стан спокою, протидіють і гальмують процес зняття внутрішніх напружень [4]. Отже, можна припустити, що охолодження суспензій до температур нижче кімнатної тільки посилить це явище і час релаксації внутрішніх напружень буде значно переважати час, необхідний для випаровування розчинника з об’єму тонкої плівки, фіксуючи таким чином структуру у напруженому стані. Очевидно, що нагрівання суспензії навпаки пришвидшує релаксацію.

Як видно з діаграм (рис. 8 та рис. 9), плівки вилиті з охолодженої суспензії, мають меншу товщину та шорсткість. Профіль поверхні плівок показаний на рис. 10.

Проведені дослідження свідчать, що за допомогою застосування методики попереднього охолодження суспензії перед литтям вдалося зменшити товщину та шорсткість плівки вдвічі. Зменшення шорсткості плівок можна пояснити комбінацією дії на суспензію високих напружень зсуву та низької температури. Високі напруження зсуву в псевдопластичній суспензії призводять до орієнтації та розрівнювання полімерних ланцюгів, а низька температура сповільнює релаксацію подібних структур на час, необхідний для випаровування розчинника, остаточно фіксуючи структуру. В результаті на поверхні плівки знаходяться більш впорядковані структурні одиниці, що призводить до зменшення шорсткості. 

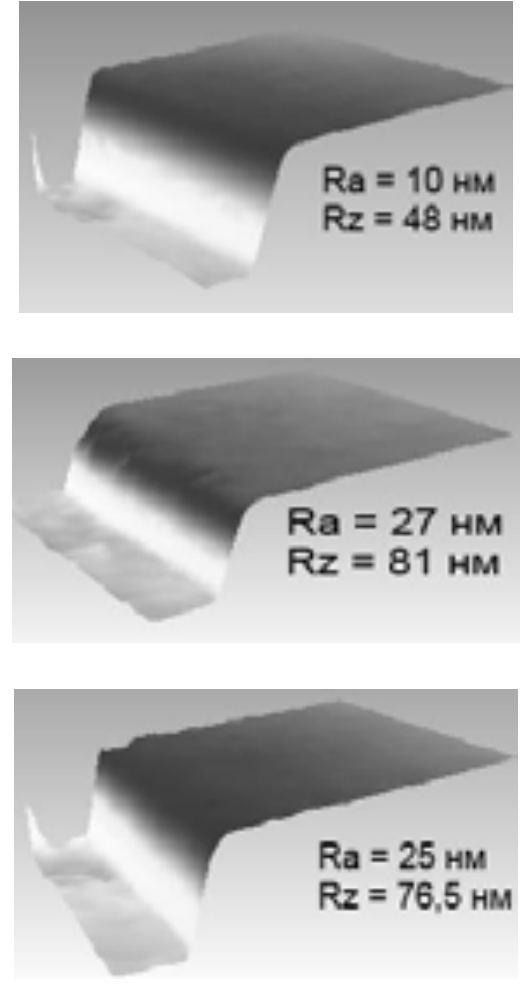

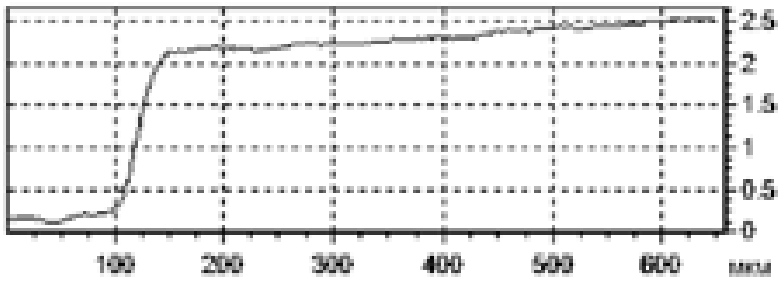

a

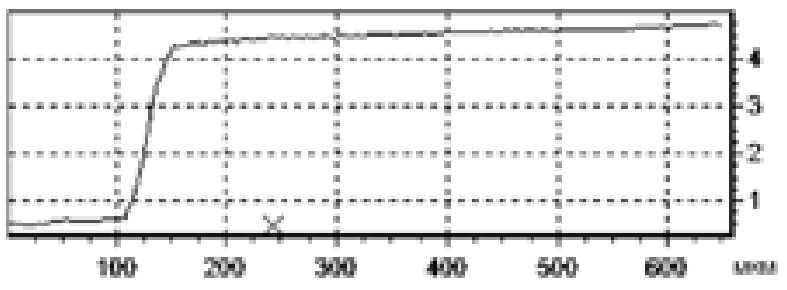

б

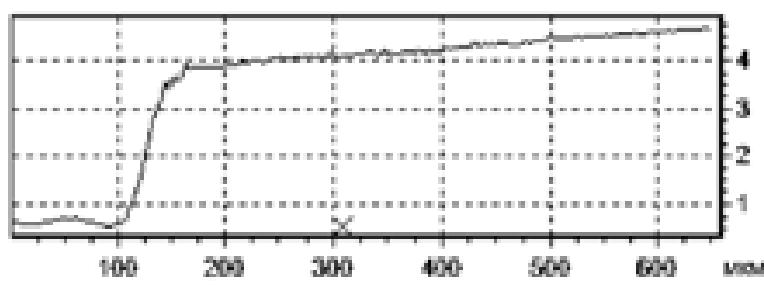

B

Рис. 10. 3D i 2D профілі плівок, отриманих із суспензій різної температури: $\mathrm{a}-5^{\circ} \mathrm{C} ; \sigma-25^{\circ} \mathrm{C} ;$ в $-45^{\circ} \mathrm{C}$.

Слід зазначити, що в даній роботі досліджувалися випадки лиття суспензій при малому зазорі філь'єри (і відповідно при високих напруженнях зсуву). При литті товстих плівок через великий зазор філь'єри ефект від попереднього охолодження суспензій може бути протилежним і проявиться у збільшенні товщини плівки, адже значення напружень зсуву будуть меншими.

Фотографії мікроструктури (рис. 11) підтверджують формування більш щільної та рівномірної структури в плівці, отриманої з охолодженої суспензії. 

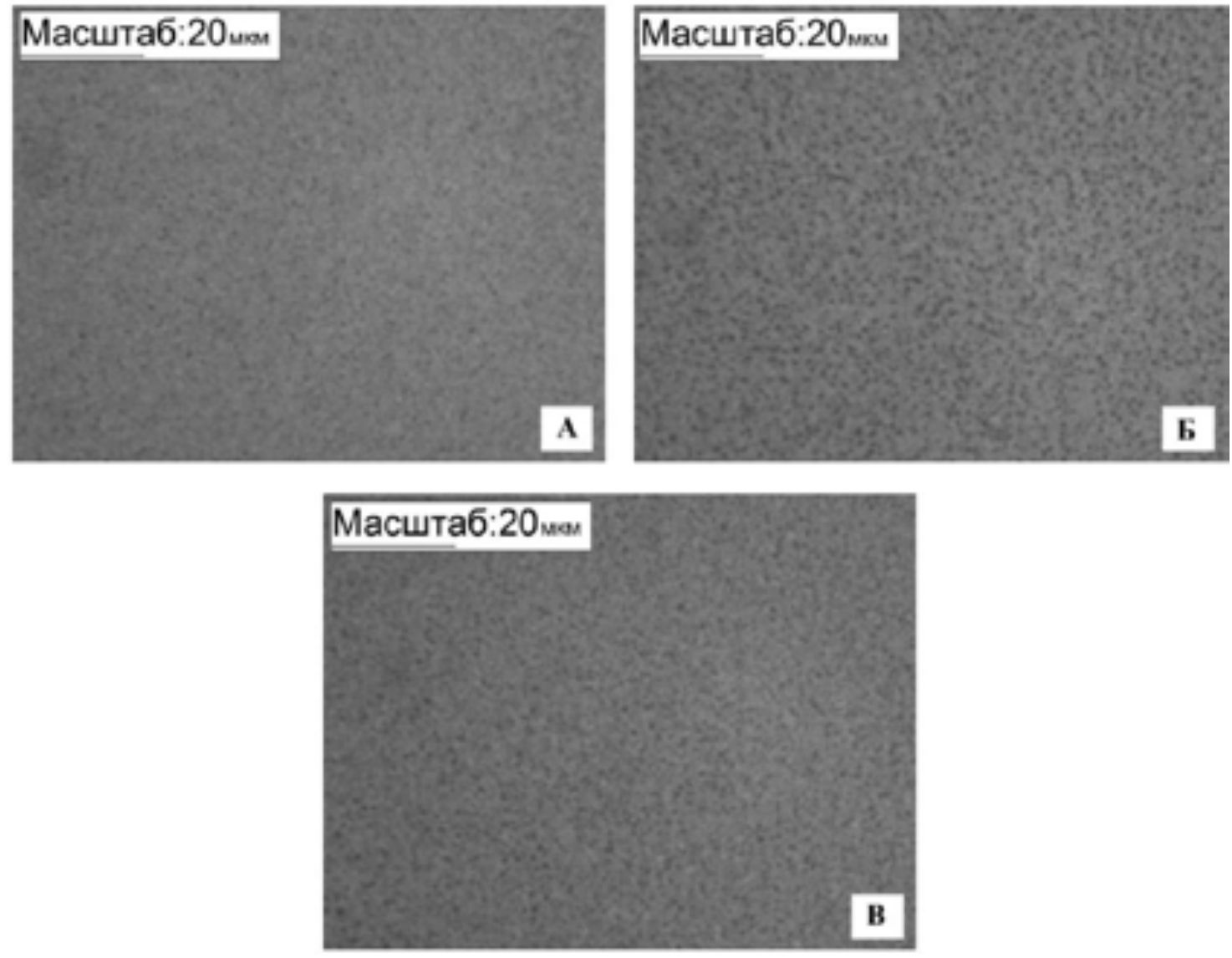

Рис. 11. Мікроструктура плівок отриманих при литті суспензій різної температури: $\mathrm{a}-5^{\circ} \mathrm{C} ; 6-25^{\circ} \mathrm{C} ; \mathrm{B}-45^{\circ} \mathrm{C}$.

\section{Висновки}

Експериментально встановлено, що попереднє охолодження суспензії перед литтям дозволяє покращити розтікання суспензії на ліофобній поверхні носія без зміни ії хімічного складу, зменшити товщину та шорсткість отриманих плівок. Високі зсувні напруження сприяють орієнтації структури плівки, а охолодження фіксує структуру в напруженому стані на час, необхідний для випаровування розчинника. Найменша товщина плівки, яку вдавалося отримати 3 досліджених в роботі суспензій при зазорі філь'єри близько 1 мкм без охолодження, склала близько 1,5 мкм. Застосувавши методику попереднього охолодження, вдалося отримати суцільну плівку товщиною близько 400 нм. При збільшенні висоти зазору філь'єри до 10 мкм позитивний ефект зберігався і дозволив отримати плівки товщиною 2 мкм, в той час як плівки, отримані з нагрітих суспензій, мали товщину 4мкм. Окрім того, в обох випадках шорсткість плівки зменшилася майже вдвічі. На процес лиття надтонких плівок методом Tape Casting критичний вплив має комбінація чотирьох основних параметрів: 
температура і в’язкість суспензії, її розтікання на носії та градієнт зрізу, що діє на суспензію під час їі проходження під лезом філь'єри. Процеси, що проходять під час лиття охолоджених суспензій, становлять практичний інтерес, адже дозволяють отримувати плівки меншої товщини та кращої якості і потребують подальшого поглибленого дослідження.

\section{Перелік посилань}

1. Greater capacity for batteries makes smaller devices (2014, September 11). Режим доступу: http://phys.org/news/2014-09-greater-capacity-batteries-smaller-devices.html (дата звернення: 23.09.2016).

2. Mistler, R.E., Twiname, E.R. Tape Casting: Theory and Practice / R.E. Mistler, E.R. Twiname // The American Ceramic Society - 735 Ceramic Place, Westerville, Ohio 43081. - 2000. - P. 298.

3. Сумм Б.Д., Горюнов Ю.В. Физико-химические основы смачивания и растекания / Б.Д. Сумм, Ю.В. Горюнов. - М.: Издательство «Химия». - 1976. - 232 с.

4. Шрамм, Г. Основы практической реологии и реометрии / Г. Шрамм: Пер. с англ. И.А. Лавыгина. - М.: КолосС. - 2003. - 312 с. 